\title{
Anterior Horn Cell
}

National Cancer Institute

\section{Source}

National Cancer Institute. Anterior Horn Cell. NCI Thesaurus. Code C12645.

A motor neuron that is located in one of the ventral horns of the spinal cord and innervates skeletal muscles of the trunk or head. 